\title{
Incidental urothelial rest within the vermiform appendix of a paediatric male patient: an extremely rare entity
}

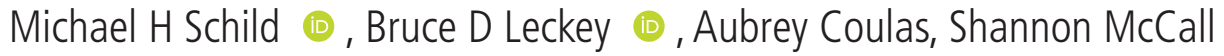

Pathology, Duke University Hospital, Durham, North Carolina, USA

Correspondence to Dr Michael H Schild: michael.schild@duke.edu

Accepted 31 December 2019

\section{DESCRIPTION}

A paediatric male patient presented with signs and symptoms of acute appendicitis and was treated with laparoscopic appendectomy. Histopathology confirmed acute appendicitis with transmural inflammation and serositis. Additionally, histopathological examination revealed an incidental, wellcircumscribed epithelial rest within the appendiceal serosa (figure 1). The rest consisted of cuboidal cells with round to oval nuclei and small nucleoli. No atypia or mitotic activity was present. Immunohistochemistry was positive for p63 and GATA-3, confirming urothelial differentiation (figure 2). Urothelial rests are common, benign, frequently incidental findings within the female gynaecological tract, where they are known as Walthard rests. ${ }^{1}$ Additionally, Walthard rests have been reported in male genitourinary organs, including the epididymis, tunica albuginea, testis and spermatic cord. ${ }^{2}$ However, they are extremely rare within the vermiform appendix, with only two previously reported cases; one in a 28 -year-old woman, ${ }^{1}$ and the other in a paediatric patient without a reported sex or age. $^{3}$ To our knowledge, this case represents the first definitive report of a urothelial rest within the vermiform appendix of a paediatric male patient.

Walthard rests were originally described by Max Walthard in 1903. Since then, multiple theories have been proposed to describe the origin of Walthard rests, including mesothelial metaplasia, metaplastic urothelium and Müllerian remnants. ${ }^{2}$ Immunohistochemistry can be used to confirm the urothelial differentiation. To render a diagnosis of a Walthard rest, no significant atypia, atypical mitotic figures
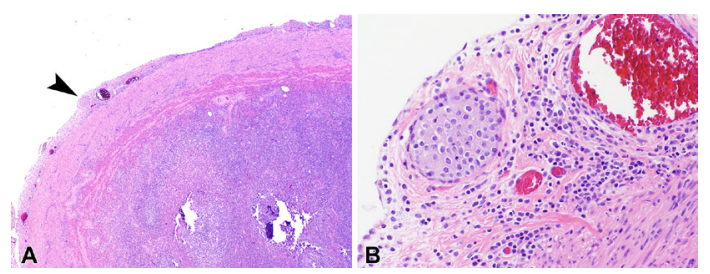

Figure 1 (A) $H \& E, 2 \times$. Acute appendicitis and serositis with a urothelial rest within the serosa (arrow). (B). H\&E, $20 x$. Urothelial rest within the serosa shows cuboidal cells, round to oval nuclei, small nucleoli, and NO atypia or mitotic figures.

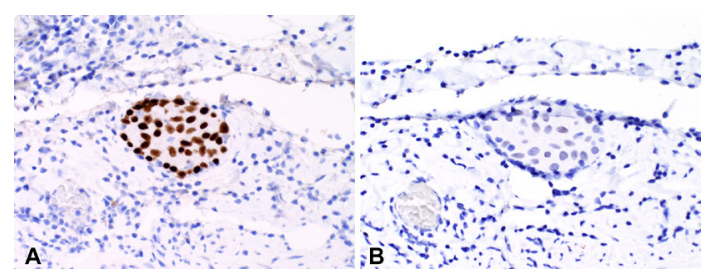

Figure 2 (A) 20x. P63 immunohistochemistry highlights the urothelial rest. (B) 20x. GATA-3 immunohistochemistry highlights the urothelial rest.

or tissue invasion can be present. Recognising the benign nature of these lesions is imperative to the patients' management, as no further treatment is required.

\section{Learning points}

- Urothelial rests are common, benign entities in the female gynaecological tract, but are extremely rare within the vermiform appendix.

- Recognising the benign nature of this lesion is imperative, as no further treatment is required.

Contributors MHS is the primary author. BDL prepared photomicrographs/figures. AC helped with writing and editing the paper, and made exhaustive attempts to contact the patient's guardians for consent. SM is the attending pathologist on the case.

Funding The authors have not declared a specific grant for this research from any funding agency in the public, commercial or not-for-profit sectors.

Competing interests None declared.

Patient consent for publication Not required.

Provenance and peer review Not commissioned; externally peer reviewed.

\section{ORCID iDs}

Michael H Schild http://orcid.org/0000-0003-3609-5649 Bruce D Leckey http://orcid.org/0000-0001-8051-0657

\section{REFERENCES}

1 Squires L, Matsika A, Allan C, et al. Incidental urothelial rests within a vermiform appendix. Pathology 2018;50:S144

2 Abdelmalak R, Jackie Cao Q, Jawale R. Cystic Walthard rests presenting as a spermatic cord Lesion-An extremely rare anatomic presentation and potential diagnostic pitfall. Am J Clin Pathol 2018; 150:S1.

3 Gorter RR, van Amstel P, van der Lee JH, et al. Unexpected findings after surgery for suspected appendicitis rarely change treatment in pediatric patients; results from a cohort study. J Pediatr Surg 2017;52:1269-72 
Copyright 2020 BMJ Publishing Group. All rights reserved. For permission to reuse any of this content visit https://www.bmj.com/company/products-services/rights-and-licensing/permissions/

BMJ Case Report Fellows may re-use this article for personal use and teaching without any further permission.

Become a Fellow of BMJ Case Reports today and you can:

- Submit as many cases as you like

- Enjoy fast sympathetic peer review and rapid publication of accepted articles

Access all the published articles

Re-use any of the published material for personal use and teaching without further permission

Customer Service

If you have any further queries about your subscription, please contact our customer services team on +44 (0) 2071111105 or via email at support@bmj.com.

Visit casereports.bmj.com for more articles like this and to become a Fellow 